Dig Dis 1997;15:368

\title{
Esophageal Foreign Body
}

\begin{tabular}{|l|l|l|}
\hline R. & Rajeev & Jain \\
\hline M. & Michael & Nunez \\
\hline
\end{tabular}

University of Texas, Southwestern Medical School, Dallas, Tex., USA

Rajeev Jain, MD, University of Texas, Southwestern Medical School, 2600 Cole Ave., 128, Dallas, TX 75235 (USA)

A 45-year-old man presented with a 4-hour history of odyno-phagia after attempting to open a beer bottle with his teeth. The pos-teroanterior and lateral neck X-rays reveal a foreign body lodged at the C-6 level. The object is aligned in the frontal plane which is consistent with an esophageal foreign body. The patient was without respiratory compromise and underwent endoscopy. A beer bottle cap was retrieved from an area just distal to the upper esophageal sphincter without complication and the patient was discharged home.

KAKGEH

E-Mail karger@karger.ch Fax+ 41613061234 http:// www. karger. ch

(C)1997 S.KargerAG, Basel 0257-2753/97/0156-0368S15.00/0

This article is also accessible online at: http://BioMedNet.com/karger 